\title{
Analysis of the flooding event of October 22-23, 2005 in a small basin in the province of Bari (Southern Italy)
}

\author{
Tiziana Bisantino, ${ }^{1}$ Vincenzo Pizzo, ${ }^{2}$ Maurizio Polemio, ${ }^{3}$ Francesco Gentile ${ }^{4}$ \\ ${ }^{1}$ Functional Centre, Civil Protection of Apulia Region, Bari; ${ }^{2}$ Geotecnologie S.R.L., Bari; \\ ${ }^{3}$ National Research Council-Research Institute for Geo-Hydrological Protection, Bari; \\ ${ }^{4}$ Department of Agricultural and Environmental Science, University of Bari Aldo Moro, Bari Italy
}

\begin{abstract}
In the province of Bari the hydrographic network consists of ephemeral streams called lame. In these watercourses the absence of runoff for long periods contributed to unfounded beliefs concerning the hydraulic safety of the landscape and therefore uncontrolled changes in streambeds and floodplains.

In these streams high water discharges can occur during heavy rainfalls, as demonstrated by the floods that hit the city of Bari in the late nineteenth and early twentieth century. The flooding event of October 22-23, 2005 can be considered catastrophic as it resulted in six deaths, numerous injuries and substantial damage sustained by road and railway infrastructures at the intersection with the hydrographic network. This study aims to analyse the severity of the event in terms of the response of the landscape with reference to the case of the lama Scappagrano basin, where a Eurostar train derailed due to the collapse of the railway embankment. Coupled hydrological and two-dimensional hydraulic modelling was performed to reconstruct the flood hydrograph and water depths on the upstream side of the embankment. The results were used to set the boundary conditions to analyse the internal stability of the embankment using a finite element method.
\end{abstract}

\section{Introduction}

The hydrographic network in the Province of Bari, Italy is of karst origin and consists of ephemeral streams called lame. For most of the \author{
Amendola 165/A, 70126 Bari, Italy. \\ E-mail: francesco.gentile@uniba.it \\ Key words: Floods; modelling; embankment stability. \\ Received for publication: 5 January 2016. \\ Accepted for publication: 13 October 2016. \\ (c) Copyright T. Bisantino et al., 2016 \\ Licensee PAGEPress, Italy \\ Journal of Agricultural Engineering 2016; XLVII:531 \\ doi:10.4081/jae.2016.531
}

Correspondence: Francesco Gentile, Department of Agricultural and Environmental Science (DISAAT), University of Bari Aldo Moro, via

This article is distributed under the terms of the Creative Commons Attribution Noncommercial License (by-nc 4.0) which permits any noncommercial use, distribution, and reproduction in any medium, provided the original author(s) and source are credited. year, this hydrographic system is completely dry due to low rainfall and high permeability of the outcropping geological formations. Rainfall from low to medium intensity becomes aquifer recharge as a result of direct infiltration or after a short overland flow. During very high intensity rainfalls the infiltration rate rapidly decreases creating streams in which runoff can reach high values (Puglisi et al., 1991).

The absence of runoff for long periods contributed to a false sense of safety in this area and led to unchecked transformations of streambeds and floodplains. These transformations created water flow obstructions, narrowing of sections and crossings of the hydrographic network.

The numerous floods that occurred in the past, and most notably at the beginning of the $20^{\text {th }}$ century demonstrate that the province of Bari is exposed to hydraulic risk. In particular, documented flooding has shown how these ephemeral streams are characterised by rapid flow variations that lead to repercussions and cause damage. After a long period without serious flooding, the event of October 22-23, 2005 refocused public concern on the issues of hydraulic safety in the landscape. On the one hand, the event highlighted the effectiveness of the structures constructed in the last century to defend the city of Bari from floods. On the other hand, it underlined the great risk to which the territories in the province of Bari are exposed. The flood called attention to the land development of the previous decades, which either did not give the lame the necessary consideration or underestimated the role of these watercourses given their dryness for prolonged periods.One of the main problems that the flood of 2005 brought to light involves the interaction between the hydrographic network and the transport infrastructures. This was demonstrated by the elevated number of crises connected with road and railway crossings. The notable dangers that these events can provoke require great attention, as was demonstrated by the collapse of the road embankment near Cassano Murge causing five deaths. In the Scappagrano lama the collapse of the railway track embankment involved the Eurostar train travelling from Taranto to Milan. The event luckily resulted in no fatalities (Figure 1). The present study analyses the interactions between the 2005 flood hydrograph and the railway embankment using a two-dimensional hydraulic model; subsequently, an evaluation of the stability of the embankment was performed with regard to internal erosion.

\section{The ephemeral stream system in the province of Bari}

The High Murgia is part of the Apulian Mesozoic carbonate platform. It can be considered a large asymmetrical horst, which descends towards the Adriatic Sea and the Salento peninsula in a series of marine terraces. The Murgia is a homogeneous unit from both a geological and morphological perspective. The lithology of the area consists of a platform of calcareous rocks dating back to the Mesozoic era. Numerous areas are covered by strips of rock with various extensions and shallow deposits of sandy calcarenite that were formed during the Pleistocene era (Ricchetti et al., 1988). 
The Mesozoic rocks, known as formations of Bari Limestone and Altamura Limestone, have a discontinuous degree of fissures with tectonic occlusions of red clays. Effective infiltration of rainfall will depend primarily on local factors, such as the degree of karst, lithofacies and type of vegetation (Romanazzi et al., 2015). The amount of precipitation in the province ranges from $800 \mathrm{~mm} \cdot \mathrm{year}^{-1}$ inland to $500 \mathrm{~mm} \cdot \mathrm{year} \mathrm{r}^{-1}$ in coastal zones. The karst phenomena created sinkholes, aside from a hydrographic network composed of lame, which are flat-bottomed channels with sub-vertical banks. This network is an ancient drainage system which today remains dry for long periods. However, in exceptional cases it reactivates transporting large volumes of water and sediments, as in other areas of Apulia region (Bisantino et al., 2010; Abdelwahab et al., 2014).

The Adriatic side of the Murgia, the Conca di Bari, consists of several lame, which originate in the northwestern area of the High Murgia and descend towards the Adriatic Sea; among the most important are lama Balice, Lamasinata, Picone, Valenzano and San Giorgio (Figure 2).

The Scappagrano basin, with an area of $23 \mathrm{~km}^{2}$ (Table 1 and Figure 2) is part of the Baronale lama basin, which is itself an affluent of the Picone stream. It extends over most of the territory of Acquaviva and is included in the landscape system of the Low Murgia, which is slightly sloped and characterised by shallow to very shallow soil in depressions, as well as by very deep and evolved soil on flat areas and valley floors (Caliandro et al., 2005).

The soil is predominately used for mixed crops, such as olive groves, fruit orchards and vineyards; there are also herbaceous crops and pastures. Small strips of natural forests (usually broad-leaved) and artificial woods (mostly conifer) are present. The planting of Aleppo Pine (Pinus halepensis Mill.) in the area was planned to protect the landscape surrounding Bari from floods (Puglisi et al., 1991).

The climate is of the Mediterranean type characterised by two main rainfall periods: one in autumn and the other in spring (Milella et al.,
2012). During autumn and winter there are many frost days; some late frost may continue into March or the beginning of April. Snowfall is an infrequent event; however, in 1956 and 1986 heavy snowfalls with depths greater than $1 \mathrm{~m}$ were recorded.

The Scappagrano basin is closed downstream by a railway running between Taranto and Milan. The railway is situated on an earth embankment with a concrete culvert. The interaction between the culvert and the morphology of the downstream zone causes the runoff to enter the culvert after having completed a $90^{\circ}$ curve to the right. The survey detail and the results obtained from the application of the hydraulic model (reported later in this study) indicate that there is another runoff path that runs parallel to the culvert axis.

\section{Materials and methods}

\section{The flooding events in the province of Bari and the flood of 2005}

Thirteen catastrophic floods were recorded from 1567 to 2007 in the province of Bari (Polemio, 2010). One of the first documented reports is from October 2, 1567, when the historian Beatillo describes a huge inundation in Bari (Alfieri, 1927). In 1813, Gioacchino Murat began the construction of a new district in Bari. His urban plan, however, did not account for the land morphology and therefore caused the filling up of the natural drainage network. This urban development, coupled with remarkable climatic events, brought about a series of dramatic events. Likewise, in September 1827 and again in August 1833 and 1881, three catastrophic floods occurred in the Picone stream.

In the century that followed, similar devastation occurred during the flood of the Picone stream in February 1905. The inundation was responsible for five deaths and damage to infrastructures. Later, the

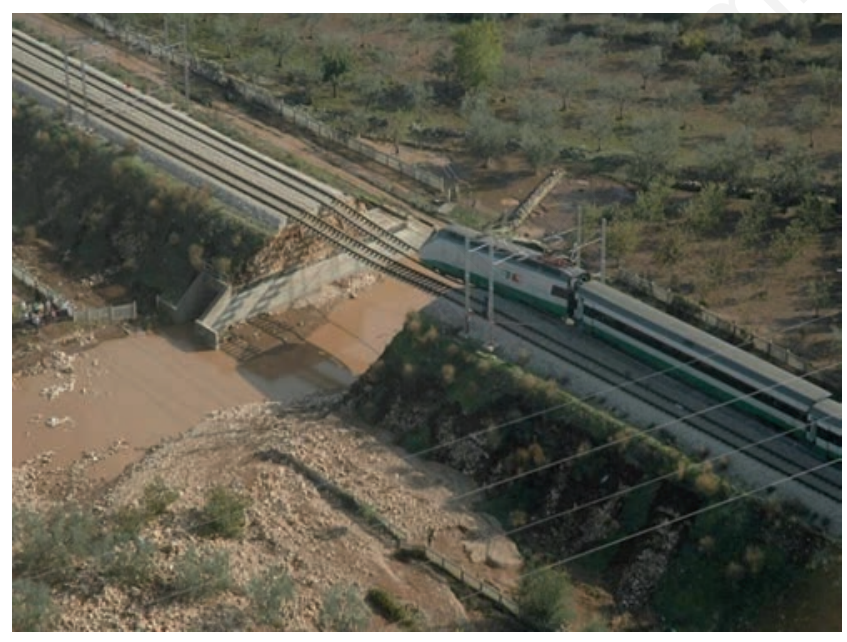

Figure 1. Collapse of the railway embankment at the Scappagrano lama.

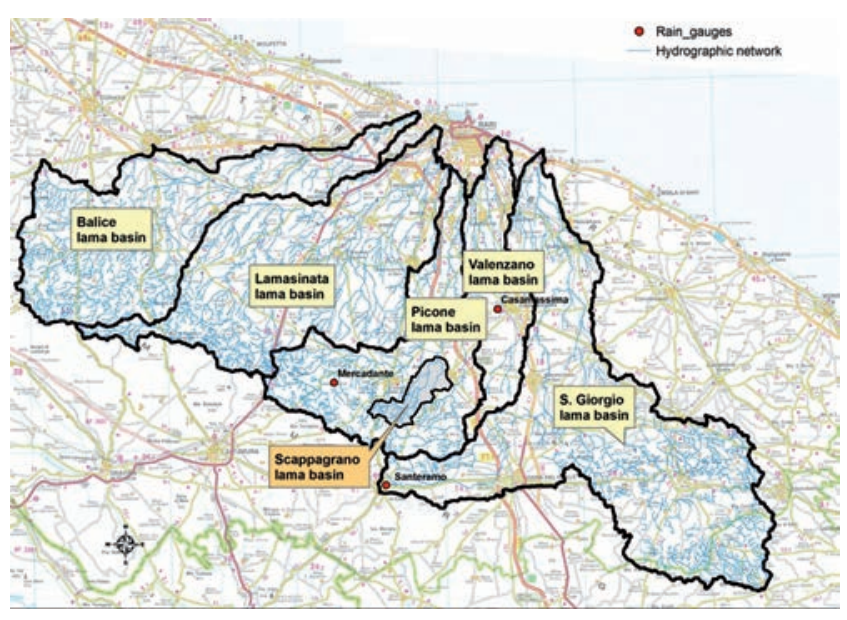

Figure 2. The main lame basins in the province of Bari. The Scappagrano basin is also reported together with the Mercadante, Santeramo and Casamassima rain gauges.

Table 1. Morphological characteristics of the Scappagrano lama basin.

\begin{tabular}{lcccccc}
$\mathrm{S}\left(\mathrm{km}^{2}\right)$ & L $(\mathrm{km})$ & Mean stream slope (\%) & Mean basin slope (\%) & Hmax (m a.s.J.) & Hmed (m a.s.J.) & Hmin (m a.s.l.) \\
23.0 & 13.3 & 1.4 & 5.0 & 473.0 & 355.5 & 271.7 \\
\hline
\end{tabular}


flooding events of September 1915 and November 1926 caused several injuries and deaths.

After the flood of 1926, a section of the Picone stream was widened and the high basin area of Picone, now called the Mercadante forest, was forested (Puglisi et al., 1991).

In the period from 1926 to 2005 no other floods occurred, with the exception of one moderate inundation in 1957, which caused damages mostly to the countryside (Milillo and Trisorio Liuzzi, 1996). In the meantime, a new push for urbanisation brought about a huge amount of construction activity that sealed off large areas of the network and expanded existing roads and railways (Mossa, 2007). In addition, many unauthorised structures were built near or inside the lame. All of these remarkable landscape transformations occurred in a context in which the role of the lame as actual watercourses was underestimated and not adequately considered in planning procedures (Romano et al., 2015).

The flood event of 2005 occurred in this altered urban landscape. Between October 22 and 23 a heavy rainfall lasting a few hours caused the flooding of the Picone stream; six deaths and many injured people were attributed to the flood. Very high damages were also reported. In addition to the embankment failure at the Scappagrano basin, the most important were the collapse of the road n. 184 between Cassano and Bitetto, which caused five deaths, the damages to a group of 70 buildings between Cassano and Grumo Appula and to the residential area called Cava di Maso near Bari. The electricity network was also severely hit, as five transformer rooms were flooded and twenty-eight power lines interrupted (Moretti, 2005). The entire transportation system was involved, as bridges, culverts and embankments in 34 sections were damaged. Many of these infrastructures had been built in the 20 years before 2005 (Polemio and Lollino, 2011).

The forecast issued by the Meteorological Office of the National Meteorological Centre (C.M.N.) at the Air Force base in Gioia del Colle for October 22 and 23, 2005 reported a circulation of south-westerly humid and unstable air for the whole Italian peninsula, with... cloudy skies and rainstorms.

By the morning of the $22^{\text {nd }}$, the instable air that formed over the Mediterranean Sea had already transformed into a storm and encountered the orographic elevations of the Murgia. By 1:00 pm the weather front had intensified and become dense over the area of Gioia del Colle, Acquaviva, Sannicandro and Cassano Murge.

The active Hydrographic Service (SIMI) rain gauges near the basin included those in Casamassima, Santeramo and Mercadante. The position of these rain gauges, reported in Figure 2, can be considered quite representative of the rainfall distribution in the study area. Figure 3 reports the semi-hourly and cumulated rainfall of the three rain gauge stations. The rainfall event had very-high intensity and short-duration, with a peak registered at the Mercadante rain gauge. The maximum precipitations for each duration $(0.5,1,3,6,12$, and $24 \mathrm{~h})$ and their return periods are reported in Table 2 . The parameters of the rainfall depth-duration-frequency curves, used to derive the return period of the event, were calculated using the Gumbel distribution. The precipitation registered at the Mercadante rain gauge reached the greater value of the return period $\mathrm{T}_{\mathrm{r}}>200$ years for a duration between $3 \mathrm{~h}$ and $12 \mathrm{~h}$, showing the nature nearly extreme of the event.
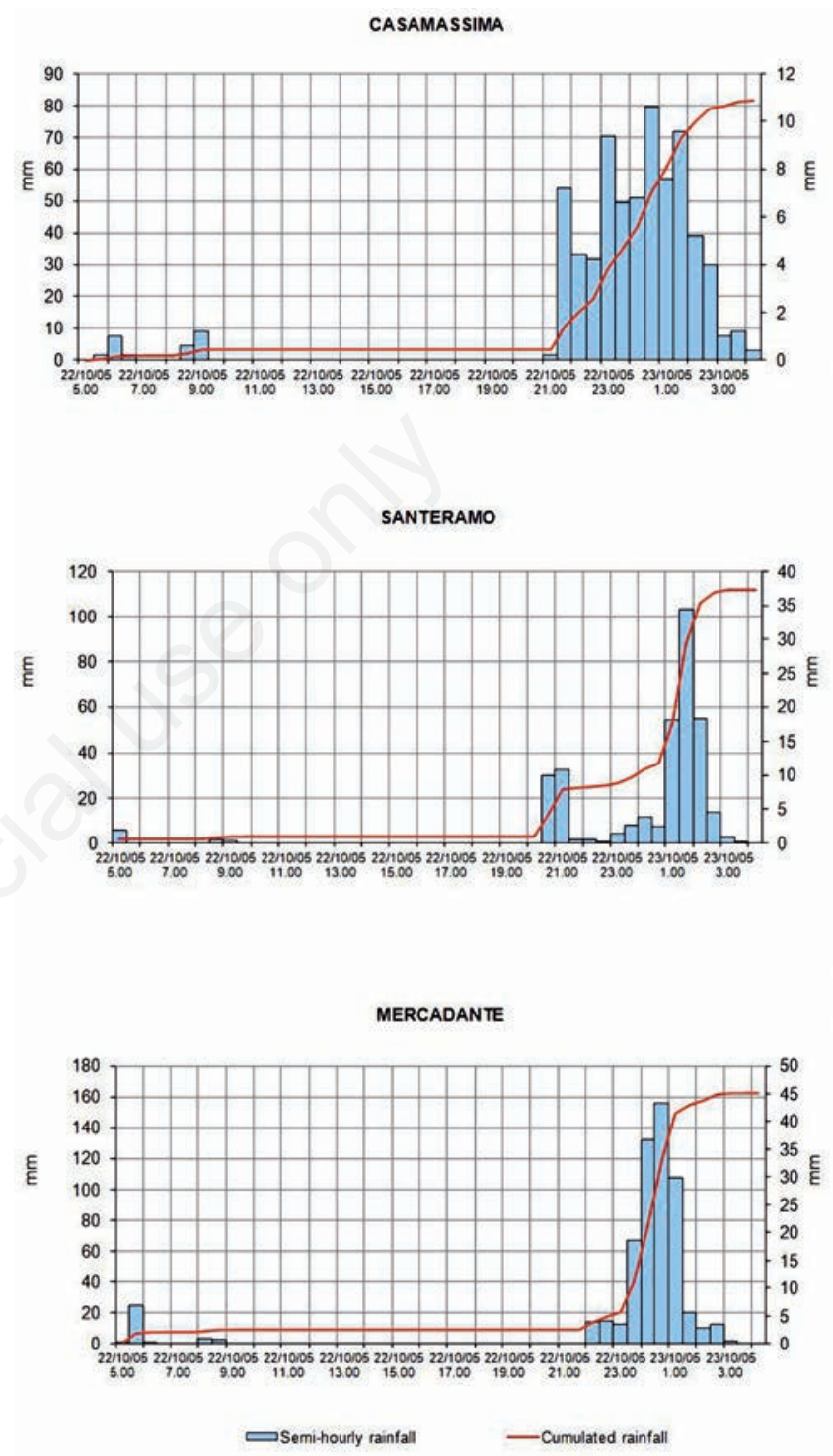

Figure 3. Semi-hourly and cumulated rainfall at the Mercadante, Santeramo and Casamassima rain gauge stations.

Table 2. Maximum precipitation for each duration and relative return periods.

\begin{tabular}{|c|c|c|c|c|c|c|}
\hline & $\begin{array}{l}\text { Maxi } \\
30^{\prime}\end{array}$ & $\begin{array}{c}\text { tensity of } \\
1 \mathrm{~h}\end{array}$ & $\begin{array}{c}\text { on }(\mathrm{mm}) \mathrm{f} \\
3 \mathrm{~h}\end{array}$ & $\begin{array}{c}23 \text { Octob } \\
6 \mathrm{~h}\end{array}$ & $\begin{array}{c}\text { d relative } \\
12 \mathrm{~h}\end{array}$ & $\begin{array}{c}\text { ne (years) } \\
24 \mathrm{~h}\end{array}$ \\
\hline Casamassima & $\begin{array}{c}11.6 \\
\mathrm{~T}_{\mathrm{r}}<10\end{array}$ & $\begin{array}{c}18.0 \\
\mathrm{~T}_{\mathrm{r}}<10\end{array}$ & $\begin{array}{c}50.6 \\
\mathrm{~T}_{\mathrm{r}}<10\end{array}$ & $\begin{array}{c}76.6 \\
20<\mathrm{T}_{\mathrm{r}}<50\end{array}$ & $\begin{array}{c}78.4 \\
10<\mathrm{T}_{\mathrm{r}}<20\end{array}$ & $\begin{array}{c}81.6 \\
\mathrm{~T}_{\mathrm{r}}<10\end{array}$ \\
\hline Santeramo & $\begin{array}{c}37.4 \\
20<\mathrm{T}_{\mathrm{r}}<50\end{array}$ & $\begin{array}{c}57.6 \\
20<\mathrm{T}_{\mathrm{r}}<50\end{array}$ & $\begin{array}{c}82.2 \\
50<T_{r}<100\end{array}$ & $\begin{array}{c}104.2 \\
100<\operatorname{Tr}<200\end{array}$ & $\begin{array}{c}108.8 \\
50<\mathrm{T}_{\mathrm{r}}<100\end{array}$ & $\begin{array}{c}112.0 \\
20<\mathrm{T}_{\mathrm{r}}<50\end{array}$ \\
\hline Mercadante & $\begin{array}{c}43.2 \\
50<\mathrm{T}_{\mathrm{r}}<100\end{array}$ & $\begin{array}{c}80.0 \\
50<\mathrm{T}_{\mathrm{r}}<100\end{array}$ & $\begin{array}{c}137.4 \\
\mathrm{~T}_{\mathrm{r}}>200\end{array}$ & $\begin{array}{c}152.6 \\
\mathrm{~T}_{\mathrm{r}}>200\end{array}$ & $\begin{array}{c}152.6 \\
\mathrm{~T}_{\mathrm{r}}>200\end{array}$ & $\begin{array}{c}162.0 \\
100<\mathrm{T}_{\mathrm{r}}<200\end{array}$ \\
\hline
\end{tabular}




\section{Results}

\section{Interaction between the railway embankment and flood discharge}

\section{Reconstruction of the flood hydrograph}

The flood hydrograph was reconstructed by applying a distributed rainfall-runoff model (Mishra and Singh, 2003), using Matlab ${ }^{\circledR}$ software. The model discretises the surface of the basin into cells coinciding with digital terrain model (DTM) grids. The estimated runoff in each cell was calculated using the Soil Conservation Service (SCS, 1972) curve number (CN) method. This method assigns each cell in the basin a $\mathrm{CN}$ dimensionless value theoretically ranging from 0 to 100 based on soil type, vegetation cover and antecedent moisture conditions. SCS subdivides the various types of soil into four hydrologic groups (A, B, C, and D), as shown in Table 3. Therefore, the $\mathrm{CN}$ values can be identified for the different areas in the basin (Figure 4). Determination of the $\mathrm{CN}$ for each cell of the coordinate $(i, j)$ in the basin enabled to define the potential maximum retention of the soil (S):

$$
S(i, j)=25.4\left(\frac{1000}{C N(i, j)}-10\right)
$$

where $S(i, j)$ is expressed in millimetres.

Based on Equation (1), the excess precipitation in each cell was estimated according to Johnson and Miller (1997). Because of an overlapping effect, the discharge at a time ( $\mathrm{t}$ ) at the outlet is calculated by the sum of the discharges provided by the single basic areas. For each cell flow time, the time the water particles travelled in the channel and on hillslopes, was calculated according to Manfreda et al. (2005). Figure 5 shows the results of the application of the hydrological model, namely, the reconstruction of the flood hydrograph of the event. The discharges started to increase the evening of October $22^{\text {nd }}$ around 10:30 p.m. and reached their maximum value $\left(Q_{\mathrm{p}} \approx 80 \mathrm{~m}^{3} \mathrm{~s}^{-1}\right)$ during the night of the $23^{\text {rd }}$ at about 1:30 a.m.

The results of the application of the $\mathrm{CN}$ method were compared with

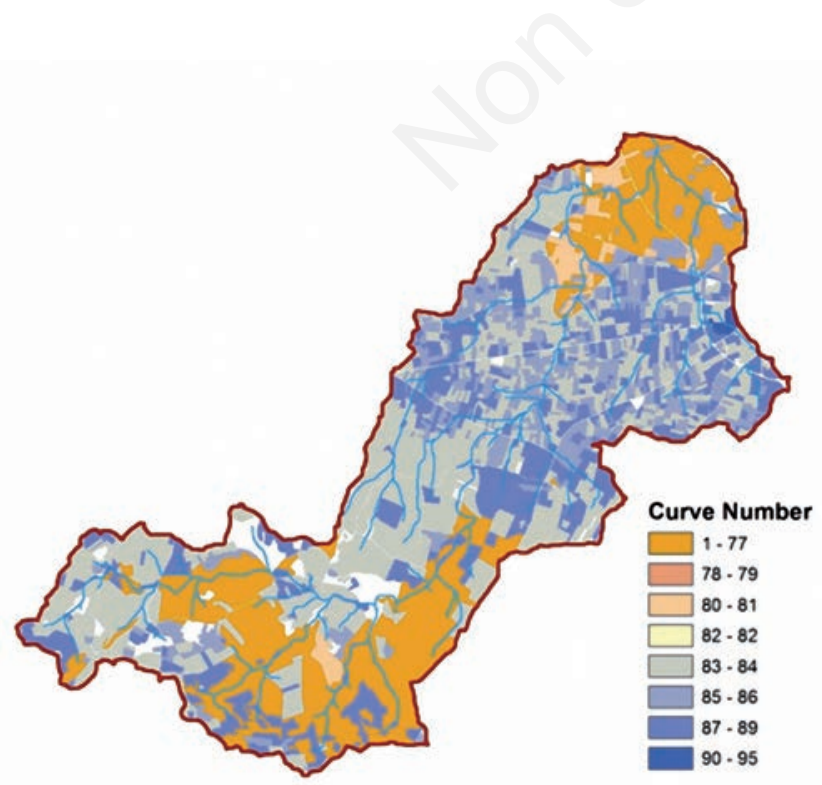

Figure 4. Curve Number map of the Scappagrano basin. those obtained using the EBA4SUB model (Grimaldi and Petroselli, 2015). The first model is capable of handling the basin heterogeneity in terms of distributed information on soil, slope and land use, while the second one is an event-based model particularly designed for small and ungauged basins, not yet tested in the lame environment. In the
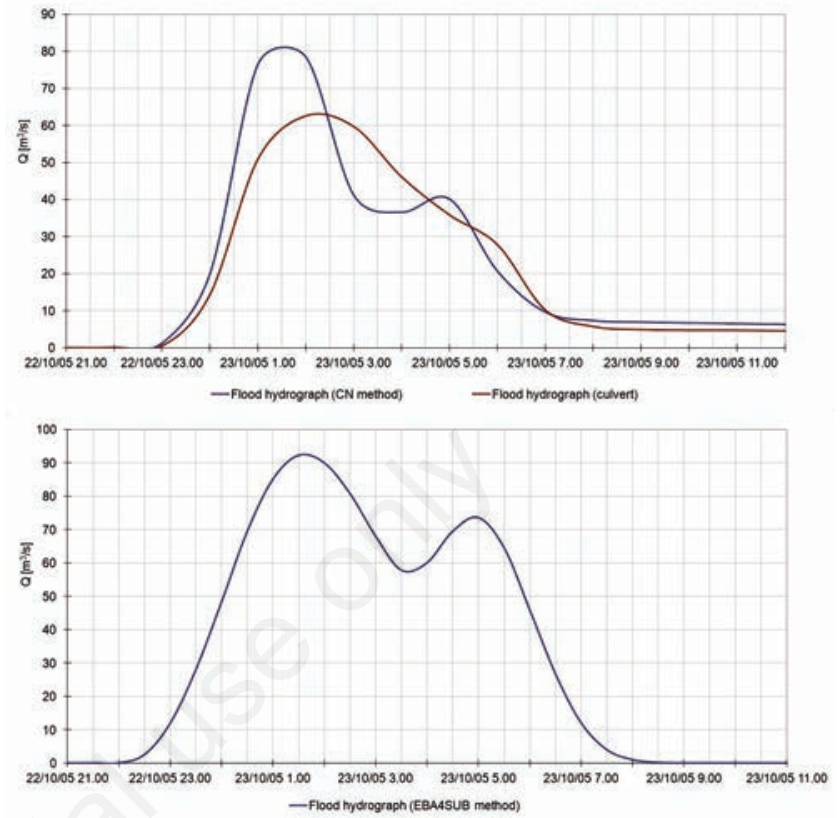

Figure 5. Flood hydrograph of October 22-23 based on the curve number $(C N)$ and EBA 4 SUB model and the peak flow reduction caused by the culvert.

Table 3. Curve number values for different land use and soil types.

\begin{tabular}{lcccc} 
Curve number values & \multicolumn{5}{c}{ Soil type } \\
Land use & A & B & C & D \\
Water bodies & N/A & N/A & N/A & N/A \\
Evergreen needless & 34 & 60 & 73 & 79 \\
\hline Evergreen broadleaf & 30 & 58 & 71 & 77 \\
Deciduous needle leaf & 40 & 64 & 77 & 83 \\
\hline Deciduous broadleaf & 42 & 66 & 79 & 85 \\
Mixed forest & 38 & 62 & 75 & 81 \\
\hline Closed shrub land & 45 & 65 & 75 & 80 \\
Open shrub land & 49 & 69 & 79 & 84 \\
\hline Woody savannahs & 61 & 71 & 81 & 89 \\
Savannahs & 72 & 80 & 87 & 93 \\
\hline Grassland & 49 & 69 & 79 & 84 \\
Permanent wetlands & 30 & 58 & 71 & 78 \\
\hline Croplands & 67 & 78 & 85 & 89 \\
Urban and built-up & 80 & 85 & 90 & 95 \\
\hline Cropland/ natural vegetation mosaic & 52 & 69 & 79 & 84 \\
Permanent snow and ice & N/A & N/A & N/A & N/A \\
\hline Barren or sparsely vegetated & 72 & 82 & 83 & 87 \\
Missing data & N/A & N/A & N/A & N/A \\
\hline
\end{tabular}

Data from Hong and Adler, 2008. N/A, not applicable. 
latter the net hyetograph is estimated by applying a procedure based on the $\mathrm{CN}$ method and the Green-Ampt equation, while the rainfall-runoff model is a particular version of the instantaneous unit hydrograph based on the width function (Piscopia et al., 2015). The flood hydrograph obtained with the application of the EBA4SUB model was similar to that produced by the $\mathrm{CN}$ method, with a slightly higher peak discharge value $\left(Q_{p}=92 \mathrm{~m}^{3} \mathrm{~s}^{-1}\right)$, as shown in Figure 5 . In the same Scappagrano basin, for the 2005 flood, Polemio (2010) estimated a peak discharge value $Q_{p}=87 \mathrm{~m}^{3} \mathrm{~s}^{-1}$, while Gabriele et al. (2006) for the same flood found a peak discharge value $Q_{p}=342 \mathrm{~m}^{3} \mathrm{~s}^{-1}$ for the entire Picone basin area; this value is very similar to that estimated by Alfieri (1927) studying the above-mentioned 1926 flood in the Picone basin $\left(\right.$ area $\left.=285 \mathrm{~km}^{2}\right)$.

\section{Flood routing}

Flood routing in the areas near the railway embankment was investigated using the hydrodynamic two-dimensional code FLO-2D. A twodimensional model is more suitable than a one-dimensional model when the components of velocity perpendicular to the direction of the main flow are taken into consideration, as in the case of lama Scappagrano.

The code generates discharges of topographically complex surfaces as those described in the DTM. It identifies the area of inundation and the velocity of the water discharge in all of the cell domains. Moreover, the model allows the simulation of discharge obstacles as well as existing waterworks (crossings, embankments, etc.). In Table 4 the parameters used and their values for FLO-2D modelling are reported.

The data required for the application of the FLO-2D code were generated using: i) a DTM with an $8 \times 8 \mathrm{~m}$ regular grid obtained in 2006 (Apulia Region Project for the development of a Regional Territorial Informative System); ii) orthophotos (2006-2007) obtained during the above-mentioned project; iii) a detailed topographical survey of the embankment; iv) the hydrographic network and basin boundary obtained with Arc Hydro tools for ArcGIS 9.2 (ESRI); v) the flood hydrograph resulting from hydrological modelling; vi) a land use map derived from the $50 \mathrm{~cm}$ pixel aerial orthophotos taken in 2006-2007 (www.sit.puglia.it). The information obtained from the land use map were used to attribute a Manning roughness coefficient value to the cells.

The grid element size (s) of the DTM should be selected to get a reasonable compromise between computational time and the spatial resolution needed to describe the floodplain elements. To reach this aim, a ratio $Q \mathrm{p} \mathrm{s}^{-1}<0.3\left(\mathrm{~m}^{3} \mathrm{~s}^{-1} \mathrm{~m}^{-2}\right)$, where $\mathrm{Qp}$ is the peak discharge value, is suggested (0'Brien and Garcia, 2009).

The characteristics of an embankment with a culvert of squared section $(3 \times 3 \mathrm{~m})$ were also considered. The functioning of this culvert depended on the shape of the opening, the type of section, roughness, and upstream and downstream water levels. A situation controlled exclusively by upstream conditions was hypothesised, since the downstream discharge was unimpeded. Under these conditions, the culvert could function on an unobstructed surface or under pressure (Chow, 1959); therefore, the associated discharge scale could be defined. Figure 5 shows the peak flow reduction caused by the culvert.

After reaching the embankment to the right of the culvert, the flow curved at $90^{\circ}$ near the culvert and could be observed during the application of the hydraulic model after $t=1 \mathrm{~h}$ from the start of the flood (Figure 6). After about $2 \mathrm{~h}$ from the start, the water levels upstream increased, as did the area of inundation. In addition, another branch of the hydrographic network flowed directly into the culvert. After about $4.5 \mathrm{~h}$ from the start of the flood, the maximum water levels had been reached (Figure 6). The coupled hydrological and two-dimensional hydraulic modelling proved to be effective in reconstructing the event and its interaction with the embankment. In fact, the water levels provided by the simulation were in a good agreement with the observable signs left on what remained of the embankment after the flood event (Figure 1).

\section{Discussion}

\section{Instability processes in an embankment}

Filtration inside an embankment is a frequent cause of instability. Indeed, the difference in hydraulic head occurring between the upstream and downstream areas of an embankment can cause filtration and bring about localised piping phenomena. In turn, piping can cause a wide range of instability, which can often be accompanied by internal failure and the ensuing collapse of an embankment. In engineering, the term piping refers to a whole series of phenomena characterised by the progressive distancing of soil particles from the solid matrix due to intergranular tangential forces produced by the seepage force of water (Lane, 1934; Terzaghi, 1939; Sherard et al., 1963).

The erosion and destabilizing processes acting on earthen structures and usually defined as piping phenomena can be distinguished as backward erosion, internal erosion, tunneling, suffusion and heave. Backward erosion occurs when an opening progressively develops at an exit inside the soil in correspondence with a section of water seepage (Foster, 1999). Internal erosion consists of the removal of smaller soil particles through seepage, which brings about the formation of zones with greater permeability. Once initiated, the process progressively increases causing a structural collapse. Internal erosion can occur in zones of preferential discharge, such as pre-existing fractures or at

Table 4. Parameters used and their values for FLO-2D modelling.

\begin{tabular}{lcc} 
FLO-2ID parameters & & \\
Manning's n coefficient & 0.15 & $\mathrm{~m}^{-1 / 3} \mathrm{~s}$ \\
DTM & $8 \times 8$ & $\mathrm{~m}$ \\
\hline Number of cells & 1933 & \\
Time of simulation & 17 & $\mathrm{~h}$ \\
\hline Culvert size & $3 \times 3$ & $\mathrm{~m}$ \\
\hline
\end{tabular}

DTM, digital terrain model.

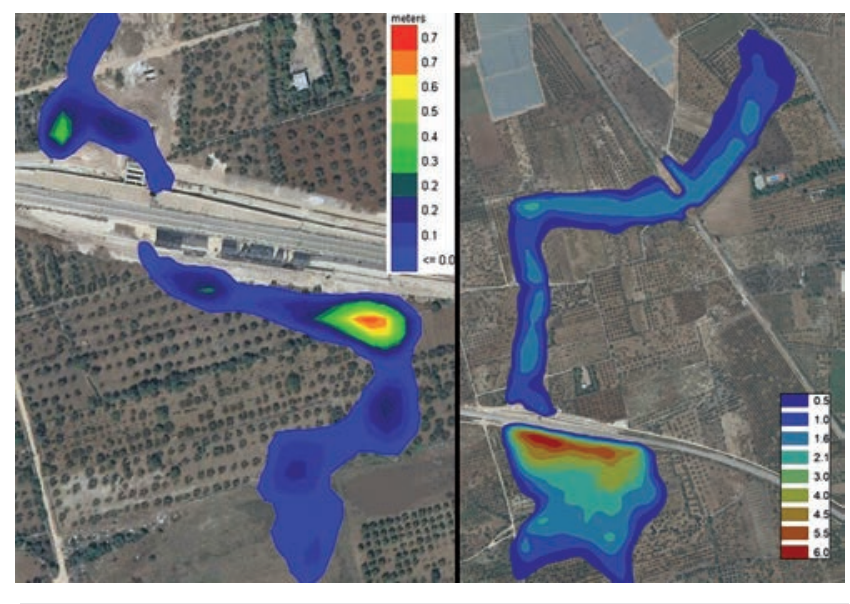

Figure 6. Detail of the upstream flooded area $1 \mathrm{~h}$ and $4.5 \mathrm{~h}$ after the start of the flood. 
borders between the ground and the structure (Lane, 1934). Tunneling is characteristic of dispersive soils, which in the presence of water produce greater repulsive versus attractive forces among fine particles. In contrast to internal erosion, tunneling most commonly occurs in areas where soil is unsaturated. Suffusion refers to the gradual migration of fine grain material through a coarse matrix by means of notable amounts of water. The loss of this fine-grained material creates a skeleton of coarse-grained soil, which will usually cause the collapse of an earthen structure. Finally, heave refers to the raising of soil downstream a hydraulic work in the presence of a vertical seepage force working from the bottom upwards (Terzaghi, 1922).

Fell et al. (2005) identified three necessary conditions for piping to occur due to the internal erosion of an earthen embankment: an upstream source of water with a high gradient value causing filtration inside the embankment; the presence of erodible material inside the embankment which can be transported by filtration; and a saturation line produced by an upstream water level that intersects the downstream side at a point above the base of the embankment.

The hydraulic gradient can be used to evaluate the potential instability of an embankment due to internal erosion after a critical value has been determined. The formula by Khilar et al. (1985, cited in Covelli et al., 2006) can be used to estimate the critical hydraulic gradient, which can trigger erosive processes in a granular material:

$$
i_{c}=0,43 \frac{1-n}{n}
$$

where $n$ represents the porosity of the soil.

A stability condition referred to internal erosion can be established by evaluating the safety coefficient $\left(\mathrm{F}_{\mathrm{s}}\right)$, which is defined as the ratio between the critical gradient $\left(\mathrm{i}_{\mathrm{c}}\right)$ and the maximum hydraulic gradient $\left(\mathrm{i}_{\max }\right)$ :

$$
F S=\frac{i_{c}}{i_{\text {max }}}
$$
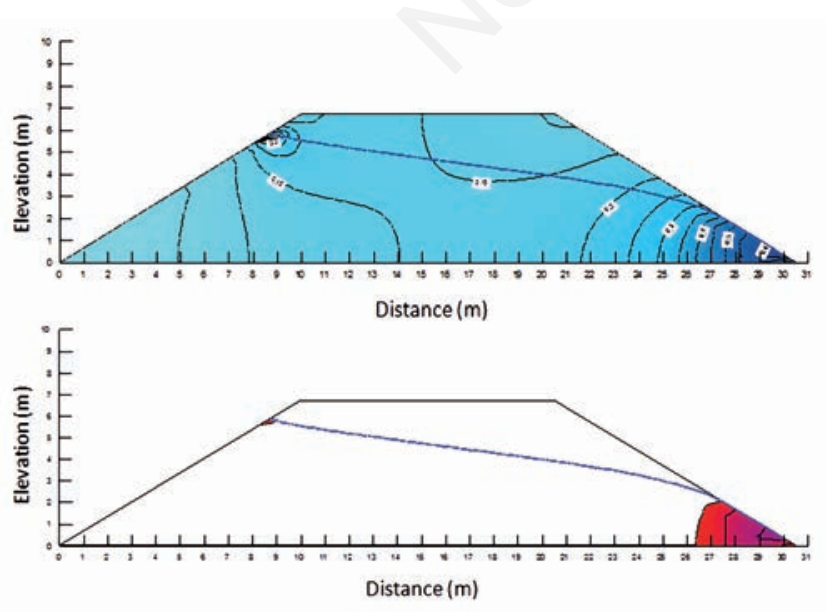

Figure 7. Distribution of the hydraulic gradient inside the embankment (for $\mathrm{k}=5 \times 10^{-3} \mathrm{~m} \cdot \mathrm{s}^{-1}$ ) and zones susceptible to erosion inside the embankment for which $F<2$.

$F_{s}$ should have a value no less than 2 in order to guarantee stability (Maione, 1998). [The literature reports a safety factor of $4 \div 5$ while taking into account the fact that breaches in an embankment are usually immediate and catastrophic, and that the heterogeneity and anisotropy of a soil is difficult to know as are construction defects (Taylor, 1948; Harr, 1962)].

\section{Modelling filtration inside the embankment}

The internal erosion process was considered to have caused the total collapse of the embankment. The filtration was modelled under twodimensional conditions using the calculation code SEEP/W at finite elements. The embankment, which was scaled according to the topographic surveys, was considered homogeneous and isotropic. The presence of vegetable soil in correspondence with the upstream and downstream embankment sides was considered not appropriate in the model, because its thickness is limited, often discontinuous, and affected by fractures of drying to the point where it cannot be considered a continuous semipermeable filter.

Moreover, the establishment of internal erosion processes could have been favoured by the presence of discontinuity zones inside the embankment that would operate as preferential waterways. These zones could be localised in particular at the soil-culvert contact, where soil compaction may not have occurred in an optimal manner. In addition, this zone could be affected by runoff along the very smooth concrete walls with enough velocity to start an internal erosion process.

A range of possible values for the hydraulic conductivity of the embankment was considered since there were no field values taken after the failure. The estimation of these values was based on the available grain size distribution (Polemio and Lollino, 2011). The material was mainly coarse with a notable fraction of silt and clay, which influenced the hydrodynamic behaviour of the soil. It was decided to model the embankment using two possible hydraulic conductivity values: $\mathrm{k}=5 \times 10^{-3} \mathrm{~m} \cdot \mathrm{s}^{-1}$ and $\mathrm{k}=5 \times 10^{-4} \mathrm{~m} \cdot \mathrm{s}^{-1}$.

In general, embankments made of loose materials are built up in horizontal layers, which can vary depending on positioning techniques and soil compaction. With this in mind, analyses of different ratios between horizontal and vertical permeability $\left(1<\mathrm{k}_{\mathrm{x}} / \mathrm{k}_{\mathrm{y}}<1.2\right)$ were carried out, but the results did not show any significant influence from
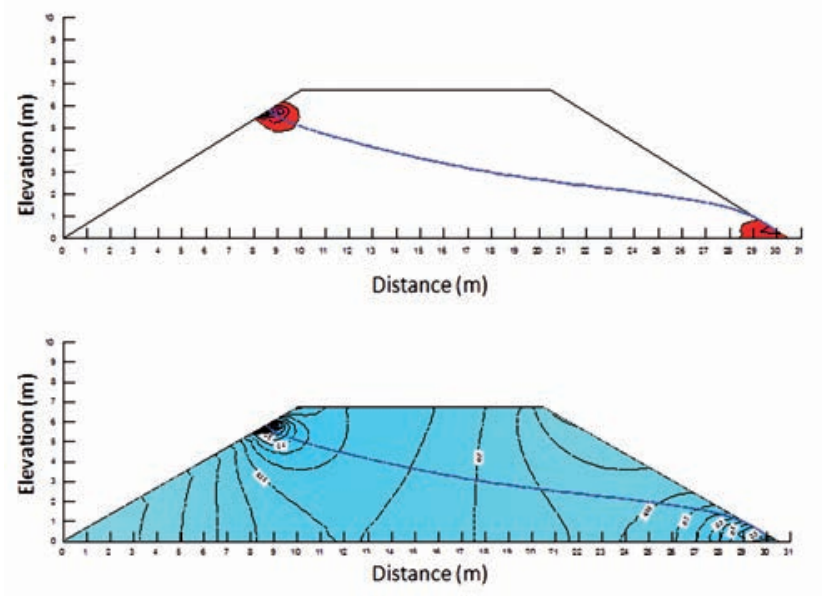

Figure 8. Distribution of the hydraulic gradient inside the embankment (for $\mathrm{k}=5 \times 10^{-4} \mathrm{~m} \cdot \mathrm{s}^{-1}$ ) and zones susceptible to erosion inside the embankment for which $\mathrm{F}<2$. 
this variation; thus the embankment was considered isotropic (Martin and Vazquez, 2013; Chen, 2015).

The modelling was initially carried out considering the initial $(\mathrm{t}=0)$ unsaturated condition of the embankment. Hence, a condition of water levels increasing in time was assigned in correspondence with the upstream side, and the process of progressive inundation was then considered taking into account the results of the two-dimensional hydraulic modelling.

The downstream side and the top of the embankment were considered as permeable borders, while the base below the embankment was considered impermeable.

The modelling of the filtration inside the embankment, for $\mathrm{k}=5 \times 10^{-3}$ $\mathrm{m} \cdot \mathrm{s}^{-1}$, showed an increasing distribution of the hydraulic gradient towards the toe of the embankment (Figure 7).

As mentioned before, the Khilar et al. (1985) formula was used to calculate the critical hydraulic gradient in order to identify the zones susceptible to erosion inside the embankment. The resulting values were compared with the hydraulic gradient values generated during filtration. A concentration of critical zones was noted at the toe of the embankment, below the point where the saturation line meets the downstream wall of the embankment (Figure 7).

Analyses were then carried out for the values of hydraulic conductivity $\mathrm{k}=5 \times 10^{-4} \mathrm{~m} \cdot \mathrm{s}^{-1}$. These results showed little divergence from the previous findings. A lowering of the saturation line was observed in the central section of the embankment caused by the increased resistance of the soil. This brought about the lowering of the exit point for the downstream saturation line and an enhancing of the critical zone in correspondence with the upstream side (Figure 8). Both Figures 7 and 8 show results that are compatible with the collapse of the embankment as observed after the flood (Figure 1).

\section{Conclusions}

In small Mediterranean basins the effects of intense floods can be very severe, as many examples in the last decade have shown. This study analyses one of these cases, the flood of 2005 in the province of Bari, when a railway embankment collapsed in the Scappagrano lama basin. The modelling approach is based on the reconstruction of the flood hydrograph using a distributed model and an evaluation of the interaction between the flood and the embankment with a two-dimensional hydraulic model; then a stability analysis of the embankment in relation to internal erosion using a finite element method is carried out. This approach has proved to be effective in the Scappagrano lama case, as the reconstruction of the water levels upstream of the embankment is found to be consistent with what occurred during the actual event, evaluated on the basis of the signs left by the flood. Furthermore, the results of the stability analysis in relation to internal erosion are consistent with the actual collapse of the embankment.

The analyses carried out shed light on two aspects. The first one is the important role that in the processes that led to the embankment failure is attributed to the hydraulic design of the railway infrastructure. As reported above, the entire transportation system was severely hit by the flood in 2005 . This means that the intersections between the lame network and the road and railway infrastructures are sensitive points in the study area; for this reason, a check of these intersections is appropriate, as in the past the stream characteristics could have caused an underestimation of the existing hydraulic risk. The second aspect is related to modelling that, as well known, is more difficult in ungauged basins and, in this case, was based on quite poor available information. In these situations the post-event investigation could have a great importance in getting useful information for a better understanding and modelling of the processes (Ruin et al., 2014). Hydrogeomorphic, geotechnical, flood response surveys as well as witness interviews framed in a correct observation strategy gain much importance (Marchi et al., 2009) and could improve the quality of the modelling. This is important not only for the comprehension of single cases, but also to amend the knowledge of the hydrological behaviour of an entire area and, as a consequence, improve its safety with regard to hydraulic risk.

\section{References}

Abdelwahab 0.M.M., Bingner R.L., Milillo F., Gentile F. 2014. Effectiveness of alternative management scenarios on the sediment load in a Mediterranean agricultural watershed. J. Agricult. Engine. XLV:125-36.

Alfieri S. 1927. L'alluvione della zona barese nel novembre 1926. Annali del Ministero dei Lavori Pubblici, Bari, Italy.

Bisantino T., Gentile F., Milella P., Trisorio Liuzzi G. 2010. Effect of time scale on the performance of different sediment transport formulas in a semiarid region. J. Hydr. Engine. 136:56-61.

Caliandro A., Lamaddalena N., Stelluti M., Steduto P. 2005. Caratterizzazione agroecologica della Regione Puglia. In Funzione della potenzialità produttiva: Progetto Acla 2. Regione Puglia, Bari, Italy.

Chen S.H. 2015. Hydraulic structures. Springer-Verlag, BerlinHeidelberg, Germany.

Chow V.T. 1959. Open-channel hydraulics. McGraw-Hill, New York, NY, USA.

Covelli C., Cozzolino L., Pianese D. 2006. Sulle cause idrauliche di innesco dei fenomeni di instabilità dei rilevati arginali. Atti del XXX Convegno di Idraulica e Costruzioni Idrauliche, 10-15 settembre 2006, Roma, Italy.

Fell R., MacGregor P., Stapledon D., Bell G. 2005. Geotechnical engineering of dams. Balkema, Leiden, The Netherlands.

Foster M.A. 1999. The probability of failure of embankment dams by internal erosion and piping. PhD Thesis. School of Civil and Environmental Engineering, University of New South Wales, Sydney, Australia.

Gabriele S., Chiaravalloti F., Cotecchia V. 2006. L'evento pluviometrico del 22 ottobre 2005 in Puglia. L'Acqua 5:37-48.

Grimaldi S., Petroselli A. 2015. Do we still need the rational formula? An alternative empirical procedure for peak discharge estimation in small and ungauged basins, Hydrol. Sci. J. 60:67-77.

Harr M.E. 1962. Groundwater and seepage. McGraw-Hill, Ney York, NY, USA.

Hong Y., Adler R. 2008. Estimation of global SCS curve numbers using satellite remote sensing and geospatial data. Int. J. Rem. Sens. 29:471-7.

Johnson D.L., Miller A.C. 1997. A spatially distributed hydrologic model utilizing raster data structures. Comput. Geosci. 23:267-72.

Khilar K.C., Fogler H.S., Gray D.H. 1985. Model for piping-plugging in earthen structures. J. Geotechn. Engine. ASCE 111:833-46.

Lane E.W. 1934. Security from under-seepage masonry dams on earth foundations. Trans. ASCE 60:929-66.

Maione U. 1998. La sistemazione dei corsi d'acqua montani. Ed. Bios., Cosenza, Italy.

Manfreda S., Fiorentino M., Iacobellis V. 2005. DREAM: a distributed model for runoff, evapotranspiration, and antecedent soil moisture simulation. Adv. Geosci. 2:31-9.

Marchi L., Borga M., Preciso E., Sangati M., Gaume E., Bain V., Delrieu G., Bonnifait L., Pogacnik N. 2009. Comprehensive post-event sur- 
vey of a flash flood in Western Slovenia: observation strategy and lessons learned. Hydrol. Proc. 23:3761-70.

Martin S., Vazquez C. 2013. Homogenization of the layer-structured dam problem with isotropic permeability. Nonlinear Anal. Real World Appl. 14:2133-51.

Milella P., Bisantino T., Gentile F., Iacobellis V., Trisorio Liuzzi G. 2012 Diagnostic analysis of distributed input and parameter datasets in Mediterranean basin streamflow modeling. J. Hydrol. 472-473:262-76.

Milillo F., Trisorio Liuzzi G. 1996. Effetti della sistemazione congiunta idraulica e idraulico-forestale del torrente Picone (Puglia). pp 569579 in Atti del Convegno "La difesa dalle alluvioni", 4-5 novembre 1996, Firenze, Italy.

Mishra S.K., Singh V.P. 2003. Soil Conservation Service curve number (SCS-CN) methodology. Water Science and Technology Library, Kluwer Academic Publishers, Dordrecht, The Netherlands.

Moretti M. 2005. Le alluvioni nel settore Adriatico delle Murge (Terra di Bari): cause geologiche e ruolo dell'azione antropica. Geol. Terr. 3:11-22.

Mossa M. 2007. The floods in Bari: what history should have taught. J. Hydr. Res. 45:579-94.

0'Brien J., Garcia R. 2009. FL0-2D Reference manual. Available from: www.flo-2d.com

Piscopia R., Petroselli A., Grimaldi S. 2015 A software package for predicting design-flood hydrographs in small and ungauged basins. J. Agricult. Engine. XLVI:74-84.

Polemio M. 2010. Historical floods and a recent estreme rainfall event in the Murgia karstic environment (Southern Italy). Zeitschr. Geomorphol. 54:195-219.

Polemio M., Lollino P. 2011. Failure of infrastructure embankments induced by flooding and seepage: a neglected source of hazard.
Nat. Hazards Earth Syst. Sci. 11:3383-96.

Puglisi S., Arciuli E., Milillo F. 1991. Il ruolo primario delle sistemazioni idraulico-forestali nella difesa di Bari dalle inondazioni. Monti e Boschi XLII:9-16.

Ricchetti G., Ciaranfi N., Luperto Sinni E., Mongelli F., Pieri P. 1988. Geodinamica ed evoluzione sedimentaria e tettonica dell'avampaese apulo. Mem. Soc. Geol. Ital. 41:57.82.

Romanazzi A., Gentile F., Polemio M. 2015. Modelling and management of a Mediterranean karstic coastal aquifer under the effects of seawater intrusion and climate change. Environ. Earth Sci. 74:115-28.

Romano G., Dal Sasso P., Trisorio Liuzzi G., Gentile F. 2015. Multi-criteria decision analysis for land suitability mapping in a rural area of Southern Italy. Land Use Policy 48:131-43.

Ruin I., Lutoff C., Boudevillain B., Creutin J.-D., Anquetin S., Bertran Rojo M., Boissier L., Bonnifait L., Borga M., Colbeau-Justin L., Creton-Cazanave L., Delrieu G., Douvinet J., Gaume E., Gruntfest E., Naulin J.-P., Payrastre 0., Vannier 0. 2014. Social and hydrological responses to extreme precipitations: an interdisciplinary strategy for postflood investigation. Weath. Clim. Soc. Am. Meteorol. Soc. 6:135-53.

Sherard J.L., Woodward R.J., Gizienski S.F., Clevenger W.A. 1963. Earth and earth-rock dams, engineering problems of design and construction. John Wiley and Sons, New York, NY, USA, pp 114-130.

Taylor D.W. 1948. Fundamentals of soil mechanics. John Wiley and Sons, New York, NY, USA.

Terzaghi K. 1922. Der Grundbruch an stauwerken und seine verhuïung. Forch-Heimer, Nummer der Wasserkraft, pp 445.

Terzaghi K. 1939. Soil mechanics: a new chapter in engineering science. J. Instn. Civ. Eng. 12:106-41. 